\title{
MAGYAR KÖZÉP- ÉS NAGYVÁROSOK VERSENYKÉPESSÉGI TIPOLÓGIÁJA ÉS HUMÁN TŐKÉT VONZÓ POTENCIÁLJA
}

\author{
VARGA VIRÁG - TEVELI-HORVÁTH DOROTTYA - HORZSA GERGELY \\ COMPETITIVENESS TYPOLOGY \\ OF HUNGARIAN MIDDLE-SIZED CITIES AND THEIR POTENTIAL \\ TO ATTRACT HUMAN CAPITAL
}

\begin{abstract}
In the context of globalization, cities and metropolitan areas are playing an increasingly important role compared to regions, in parallel with growing urban-rural disparities. In addition to economic factors, social and cultural factors that make a city attractive to young, creative populations play a more important role than ever before.

The research attempts to typify the fifty-eight Hungarian middle and large sized cities with more than twenty thousand inhabitants on the basis of their infrastructure, as well as their economic and socio-cultural characteristics. It then presents the behaviour of different city types based on additional variables. Relevant variables were selected by principal component analysis, then the investigated settlements were classified into five clusters based on the four principal components. Also, a secondary analysis has been done to examine correlations between cluster membership and demographic characteristics of the member cities (percentage of young people between 20-39, of the educated population, and of population commuting, population size). Regarding cluster membership along with the rate of young people between 20-39 there was no significant difference.

Examining the members of the clusters, it can be seen that Budapest plus its agglomeration have an even greater spatial structural effect than expected. Another important result is that the present cluster analysis shows unquestionably the east-west division of Hungary. However, there are also clear developmental breakdowns along the distribution of past or present industrial production.
\end{abstract}

Keywords: urban competitiveness, settlement typology, human capital

\section{Bevezetés}

A globalizációs és urbanizációs tendenciák egyre nagyobb mértéket öltő folyamatával párhuzamban ma már a városok széleskörú hálózata kapcsolódik be a szolgáltatások, munkaerő, valamint a tôke nemzetközi áramlásába, elősegítve ezzel a gazdaság világméretúvé válását. Az uniós törekvések irányába ható területi kohéziós direkció a metropolisztérségek mellett felértékeli a közép- és nagyvárosok szerepét, amelyek policentrikus struktúrába szerveződve allokálhatják legkedvezőbb módon erőforrásaikat a világméretú értéktermelés helyi folyamatai számára (WATERHOUt, B. et al. 2005, KovÁCs Z.-SZABÓ T. 2013, BURGER, M. J. et al. 2014). Mivel az előbbiek által egyre fontosabbá válik a városok növekedéshez és jóléthez való hozzájárulása, kiemelt figyelmet kell szentelnünk ezen entitásoknak a globális versenyképesség kontextusában (LEFF, S.-PETERSEN, B. 2015).

E tendenciával párhuzamosan, egyfajta szemléletváltást hozva, a gazdasági tényezők mellett a társadalmi és kulturális faktorok szerepének erősödése figyelhető meg a városok humán tőke vonzó és megtartó képessége tekintetében - ezáltal emelve e puha tényezőket városi versenyképességi indikátorrá.

Kutatásunk célja infrastrukturális, gazdasági és társadalmi-kulturális jellemzőik alapján, induktív módon elkészíteni az összesen ötvennyolc magyarországi közép- és nagyváros 
versenyképességi tipológiáját humán tőke vonzó potenciáljuk bázisán. Az így létrehozott tipológia segítségével olyan kérdések megválaszolására törekszünk, hogy milyen területi mintázatokat mutat a közép- és nagyvárosok versenyképességet meghatározó humán tôke vonzó potenciálja; milyen erôs szerepet játszik ebben Budapest térszerkezeti hatása; továbbá, hogy milyen egyéb szocio-ökonómiai és demográfiai változók mutatnak kapcsolatot a humán tőke vonzó képesség tekintetében vett klaszterhovatartozással.

\section{A városok versenyképessége és sikeressége, valamint a humán tơke vonzása és megtartása}

Az egységes fogalmi meghatározás szerint a versenyképesség „a vállalatok, iparágak, régiók, nemzetek és nemzetek feletti régiók képessége relative magas jövedelem és relatíve magas foglalkoztatottsági szint tartós létrehozására, miközben a külgazdasági (globális) versenynek ki vannak téve” (EC, 1999: 75; LENGYEL I. 2000: 974). MEYER-STAMER, J. (2008) bevezette a rendszerszemléletû versenyképesség fogalmát, melyben a magas és növekvő jövedelem létrehozására való képesség mellett a helyi lakosság megélhetésének (livelihoods) javítását is hangsúlyozta. E diskurzus mentén bontakozott ki az AININGER, K.-Firgo, M. (2015) szerzópáros továbbá STigLiTz, J. E et al. (2010) értekezése, akik a társadalmi haladás, a jólét és jóllét fogalmát helyezték előtérbe, kontrasztot állítva a gazdasági növekedés egyoldalú, a GDP jelentőségét túlhangsúlyozó felfogásnak. ERDŐsI F. (2002) megállapítja, hogy a városközi verseny valódi tétje és mértéke az életminőség, amely magába foglal olyan puha tényezóket is, mint a természeti, valamint az épített környezet, a táj arculata, múvészeti értékek, kultúra. Látható tehát egy eltolódás a korábbi, pusztán gazdasági, anyagi szemlélet irányából egy szociálisan érzékenyebb, emberközpontúbb megközelítés felé. Fontos kiemelni továbbá, hogy a regionális versenyképesség elemzésében, a gazdasági növekedés és fejlődés magyarázataiban egyre inkább az endogén jellegú értelmezések kerülnek a fókuszba, hangsúlyozva a tudásbázis, a kutatás-fejlesztés, az innovációs miliő, a klaszterek, hálózatok, a humán tôke, valamint a bizalom szerepét (VARGA A. 2009, Horváth Gy. 2013, Lengyel B. 2013, LuX G. 2013, CAPello, R. 2015, Fischer, M.-NiJKAMP, P. 2014), egyre nagyobb jelentőséget tulajdonítva az innovációs potenciálnak - mint a területi versenyképességet is befolyásoló tényezőnek - melynek legfontosabb elemei a technológiai és tudástranszfer, az innovációs szolgáltatások, valamint az elérhető adattömeg, a helyi és regionális környezet (a lakókörnyezet továbbá a kulturális szolgáltatások) (RECHNITZER J.-GROSZ A. 2005).

A versenyképesség e tág értelmezése vezet el a városok sikerességének megértéséhez. HERBERT, D. - SMith, D. (1989) szerint a sikeres városban a tercier szektor térnyerése jellemző, melyben az értékhúzó ágazatok nagy számban jelen vannak, s a felértékelődő tudás által kiemelt szerepet kap a K +F és az innovációs képesség. LuKÁCs G. (2008) a magasan kvalifikált munkaerő, valamint az általa fejlődő gazdaság fontossága mellett olyan tényezőknek is kulcsszerepet tulajdonít a települési siker érdekében, mint a könnyú megközelíthetőség, elérhetőség, a megfelelő színvonalú (szociális) infrastruktúra, illetve az üzleti szolgáltatások megléte, hangsúlyozva emellett a szolidaritás és cselekvőkészség fontosságát, valamint a kulturális, múveltségi, történeti, helyi közösségi, attitûd- továbbá mentalitásbeli feltételeket. Ezzel párhuzamban BóDi F.-BőHM A. (2000) a települési siker tekintetében olyan puha elemek elengedhetetlenségét írják le, mint a hagyományos polgári értékek, az identitás, az empátia, az újra való nyitottság, továbbá egy kapcsolati háló megléte. Mindezek mellett azonban nem elhanyagolható a sikeresség demográfiai vonatkozása sem (SzÁsz A. 1984). 
A városok versenyképessége, illetve sikeressége tehát nem csupán hagyományos erőforrások (tôke, munkaerő, infrastruktúra) függ vénye, hanem olyan addicionális tényezőkön is múlik, melyek az adott terület endogén fejlődését is táplálják. Ezeket összefoglaló néven területi tőkének (CAMAGNI, R. 2005, 2008, 2009) nevezhetjük. Ide sorolható a földrajzi elhelyezkedés, a méret, a termelés szintje, a klíma, tradíciók, természeti eróforrások, életminőség, üzleti inkubáció, ipari parkok, üzleti hálózatok, szokások, informális szabályok, szolidaritás, közös támogatások, ötletek találkozása, környezet (OECD 2001). A területi tôke elmélete figyelembe veszi, hogy a gazdasági fejlődés nem minden esetben segíti közvetlenül a társadalmi jólét elérését (BARCA, F. 2009; OECD 2001: 16), újszerűsége pedig abban rejlik, hogy a korábban mérhetetlennek vélt immateriális javaknak ugyanolyan értéket tulajdonít, mint a materiális tőkének (FABBro, S.-Mesolella, A. 2010). Az endogén növekedéselmélet szerint a regionális gazdasági folyamatokban a területi tôke humán tôkeelemei kulcsszerepet kapnak, mert a térség helyi erőforrásait és attraktivitását egyszerre fejlesztik (JóNA Gy. 2013). A humán tőke szerves részét képezi a kulturális tôke (BOURDIEU, P. 2004), amely azért nyer egyre nagyobb szerepet, mert a tudás és emellett a szélesebb értelemben vett kultúra gazdasági tőkévé alakítható (JóNA,Gy. 2013).

A globális versenyben az immateriális javak, amilyen a tudás vagy a kapcsolati tôke, napjainkra a gazdasági fejlődés egyik legfontosabb mozgatórugóivá, a termelés fó erejévé váltak (LuKovics M.-ZuTi B. 2014). A magasfokú szakértelem megtartása, vonzása így egyre nagyobb értéket képvisel a városi versenyképesség és gazdasági teljesítmény tekintetében, így a városoknak képessé kell válniuk egy olyan tudásbázis vonzására, illetve megtartására, mely aztán magával hozza a tôkebeáramlást is (GLossop, C. 2008).

То́тн K. (1982) a települések népességmegtartó képessége tekintetében a helybeli munkalehetőségek és az ingázás feltételeinek társadalmi elfogadottságát emeli ki a lakosság alapellátásának biztosítása mellett, melybe beleérti az út- és járdahálózat, a lakáskörülmények, a kereskedelmi ellátottság és forgalom, az egészségügyi ellátás, valamint az oktatási intézmények meglétét. MATOLCSI L. (1982) ezt kiegészítve a közéletiség színtereinek is nagy szerepet tulajdonít, melyek segítséget nyújtanak az erős társadalmi kohézió mellett a lakosok településhez való érzelmi kötődésének elérésében. BAKOs L.-né et. al. (1985) az előbbiek mellett figyelmet fordított az élve születés és a vándorlási egyenleg arányára, a közlekedés helyzetére, a foglalkoztatási szerkezetre, valamint a kereskedelmi kapcsolatokra. SALÁNCZI I.-FEKETE T. (1985) elsődleges tényezőként a foglalkoztatottságot vizsgálta. Eredményeik azt tükrözik, hogy a településeken, ahol a munkalehetőség korlátozott, onnan a lakosság elvándorol és a település nem fejlődik. Azokon a településeken nagyobb a népességmegtartó képesség, ahol nagyobb az egy főre jutó bruttó jövedelem és az éves munkabér, korszerúbb a lakásállomány, jobb a kiskereskedelmi egységekkel, az egészségügyi s oktatási intézményekkel való ellátottság.

KolTAI Z. (2005, 2015, 2019) kutatása alapján pedig láthatóvá vált, milyen szempontokat részesít előnyben a magyar lakosság lakóhelyének értékelésekor, melyek közül a legfontosabbnak ítélt tényezők a települési-, továbbá közlekedési infrastrukturális adottságok, valamint a foglakoztatási körülmények, a helyi egészségügyi szolgáltatások és a lakókörnyezet állapota. Kevésbé lényegesek az oktatási feltételek, a városi szerepkörök szélessége, a szabadidő eltöltésének lehetőségei, a település természeti adottságai, illetve a lakásállományt jellemző vonzerő. A legalacsonyabb értéket pedig a település demográfiai adottságai és a lakóhely történelme, tradíciói kapták. A felsorolt tényezőkön kívül vonzó tényezőként fordultak még elő az emberi (családi, baráti) kapcsolatok, a közösség megléte, a közbiztonság színvonala, mindemellett pedig a lakosság etnikai összetétele. A fiatalok (15-29 éves korcsoport) körében az átlagosnál magasabb értéket kapott a szabadidő eltöltésének lehetősége, míg a korosztály számára a település történelme, tradíciói a legkevésbé 
meghatározó a lakóhely értékelésénél. A felsőfokú végzettségú csoport esetében pedig az átlagosnál magasabb pontszámot kapott az oktatás, a települési infrastruktúra, a városi szerepkörök szélessége, valamint a természeti adottságok mutatószáma.

A felsőoktatás elérhetőségének fontosságára következtethetünk JANCSó T.-SzALKAI G. (2017) elemzéséből, amelynek egyik eredménye, hogyha egy bizonyos távolságon belül nem található felsőoktatási intézmény, akkor a regionális központok felsőoktatási intézményeinek vonzáskörzetén kívül eső területekről a továbbtanulók nagyobb eséllyel választják Budapestet.

A népességmegtartás és az élhetőség szempontjából érdekes szempontot emel ki LőRINCZ K. et. al. (2020) friss kutatása. A tanulmány a városi jogállású települések között megkülönböztet közép- vagy kisvárosokat, illetve városias jellegű településeket. A város történeti fejlődése, valamint a városstruktúra is jelentős szerepet játszhat a lakóhelyválasztásban.

\section{Közép- és nagyvárosok helyzete a magyarországi településszerkezetben - történeti áttekintés}

A városok közötti versenyben jelentős szerepet játszik egy-egy város demográfiai helyzete (KőszeGFALVi Gy. 2014). Az elöregedés, a szelektív migráció és a képzett lakosság arányának csökkenése jelentôs kihívás elé állítja az érintett településeket. Ez a folyamat Magyarországon nem csak a kisebb településeket, hanem minden második városi településegyüttest is érinti (LENGYEL I.-VAS Zs. 2015). Magyarország jelenlegi térszerkezete, „vízfejúsége” alakulásában fontos szerepet játszott Trianon, a korai és a kései szocialista településpolitika (Nagy-Budapest létrehozása 1950-ben, az 1971-es Országos Településhálózatfejlesztési Koncepció implementációja), illetve a rendszerváltozás (Csomós Gy. 2009, BELuSzKy P. 2014). Az államszocialista időszak településhálózat múködését leginkább a felülről való irányítottság, valamint a szabványosított intézményhálózat jellemezte. Az akkori szabályozás homogenizált, hierarchikus és koncentrált településrendszer létrehozására törekedett, amely az - elsősorban ipari profilú - nagyvárosok favorizációja ellenére alulurbanizált maradt. Ezt jól mutathatja az ingázás jelenségének a korszakban való tömegessé válása is (BELUSZKY P.-GYóRI R. 1999).

A rendszerváltás után az 1990-es önkormányzati törvény biztosította a települési önrendelkezést és egy decentralizáltabb településhálózatot hozott létre (BELUSZKY, P.-GYŐRI, R. 1999), bár ennek a decentralizációs folyamatnak az első kudarcai a 2000-es évek végén újracentralizációs válaszokat eredményeztek (PÁLnÉ Kovács I. 2014). A túlzottan Budapest súlyú gazdasági térszerkezet oldására szakpolitikai törekvésként, mind a 2005-ös (SALAMIN G. et al 2005), mind a 2014-es országos területfejlesztési koncepció (SALAMIN G. et al 2014) a regionális jelentőségú városok célzott fejlesztését szorgalmazták.

A rendszerváltás utáni térszerkezetet jelentősen befolyásolta, hogy a telephelyválasztást kevésbé a politikai döntések, mint inkább a piaci verseny kezdte meghatározni. Egy másik jelentős változás volt a városhierarchia lazulása, amelyet többek között a várossá nyilvánítás liberalizációja továbbá a megyei szint háttérbe kerülése eredményezett. Harmadrészt, megjelent a „hátrányos helyzetư térség” fogalma a szakpolitikában, illetve a szakpolitikai diskurzusban előtérbe került a kistelepülések feltűnően kedvezőtlen demográfiai helyzete, illetve a településhálózatból hiányzó nagyobb középvárosok (BELUSZKY P.-GYőRI R. 1999, SALAmin G. et al. 2008).

A 2008-as gazdasági válság hatással volt a magyar közép- és nagyvárosok versenyképességére, de teljesen eltérő mértékben. A válság nagyobb hatással volt azokra a településekre, amelyek korábban sikeresebben integrálódtak a nemzetközi piacba (EGEDY 
T. 2012; NeMES-NAGY J.-LőCSEI H. 2015), illetve azokra, amelyek kevésbé diverzifikált gazdasági profillal rendelkeztek - gyakran egy jelentős foglalkoztatóval (MoLNÁR E. et al. 2018). A jelenlegi magyarországi térszerkezet vonatkozásában a szakirodalom több tengelyt, törésvonalat megnevez. A duális megközelítések közül a kelet-nyugat megosztottság mellett a Budapest-vidék dichotómia emelendő ki (BELusZKY P.-GYôRI R. 1999; NeMES-NAGY J.-LóCSEI H. 2015). Ezzel szemben a triális (háromosztatú) térbeli fejlődés koncepciója Budapest és a vidék között egy harmadik településcsoportot is azonosít: az FDI-vezérelt feldolgozóipari térségeket (Győr, Székesfehérvár, Tatabánya, Kecskemét) (SAlamin G. et al 2016).

\section{Magyar településtipológiák, városrangsorok}

Az elmúlt húsz évben ugyan több magyar kutató vizsgálta kvantitatív módszerekkel, komplex mutatóval Magyarország településhálózatát, valamint annak változásait, de jelen kutatás számos innovatív jellemzőjében eltér ezektől. Egyrészt, a mutatók összeállítása során különös figyelmet fordítottunk a versenyképesség puha tényezőire, szemben a korábbi kutatások kemény, gazdasági növekedésre fókuszáló szemléletével. Másrészt, a komplex mutató a versenyképesség mérésére saját fejlesztésű, BigData adatforrásokon alapuló mutatókat is tartalmaz. Mindemellett, a városok szerepének növekedése ellenére többségben vannak a térségi (kistérségi/járási, megyei, régiós) szintû elemzések, amely igazolja jelen kutatás relevanciáját. A releváns kutatások között egyedül BELUSZKY P.-GYŐRI R. (1999, 2004) kutatásai vizsgáltak hasonló elemszámú várost, mint a jelen kutatás, de az ezen kutatás által vázolt kép mára több mint tizenöt éves.

Az elemzések egy része a vizsgálatba bevont városokat csoportosította (BELUSZKY P.-GyőRi R. 1999; BEluszKy P.-GyőRi R. 2004; REChNitZER J. et al. 2004; Egedy, T. 2012; Csomós Gy. 2016; Rechnitzer J. et al. 2014; LenGYel I.-VAS Zs. 2015), míg másik részük a komplex mutató alapján városrangsort állított fel (AMBRUs Z. et al. 2008; Makra L.-Sümeghy Z. 2010; Tóth B. I. 2011; Tóth B. I.-NAgy Z. 2013, PéLi L. et al. 2017; MolNÁR E. et al. 2018), vagy a várostérségek komplex versenyképességét értékelte (SAlAmin G. 2004) (lásd 1. táblázat). Bár mind a bevont települések köre, mind a komplex mutató változói, mind az elemzési módszertan eltérők, kutatásunk szempontjából érdemes összevetni ezeket az eredményeket.

A településtipológiákat kidolgozó kutatások közül BELUSZKY P.-GYŐRI R. (1999) munkája adja az egyik legrészletesebb áttekintést az ezredforduló Magyarországának településhálózatáról, amelyben kvalitatív módon jellemzik a magyar kis- és középvárosokat, majd dinamikájuk szerint öt kategóriába sorolják őket (dinamikusan fejlődo, növekvő városok; mérsékelt dinamikájú városok; stagnáló városok; pozícióikban visszaeső, stagnáló-hanyatló városok továbbá csökkenő méretű, hanyatló városok). BELUSZKY P.-GYőRI R. (2004) longitudinális vizsgálatot is végeztek, melynek keretében a magyar közép- és nagyvárosok egymáshoz viszonyított pozícióinak változását elemezték melynek eredményeként négy csoportot különítettek el.

RECHNITZER J. et al. (2004, 2014) huszonhárom innovációs szempontból kiugró magyar várost hasonlított össze, melyeknek hat innovációs klaszterét különböztette meg. A magyarországi városok rangsorát kidolgozó kutatások közül AMBRUs Z. et al. (2008) a vállalkozássû́rűségi, beruházási, külföldi befektetésekre, lakásépítésre vonatkozó adatok alapján Győr és Székesfehérvár kedvező helyzetét emeli ki. MoLnÁR E. et al. (2018) a nyolc legnagyobb magyar város települési gazdasági erejét hasonlítja össze. A területi tôke szempontjából hasonló városi rangsorolásra vállalkozott TóтH G.-NAGY Z. (2013) is, akik 
- felismerve, hogy a regionális központok gazdasági teljesítménye csak agglomerációjukkal együtt értelmezhetó és elemezhetô - a nagyvárosi településegyüttesek fejlettségét vizsgálta. EGEDY T. (2012) a magyar városok helyzetét a válság hatásai szempontjából vizsgálta.

Jelen kutatással összehasonlítható kutatást végzett TótH B. I. (2011), LENGYEL I. - VAS Zs. (2015), illetve Csomós Gy. (2016) is, így ezeket a munkákat a kutatási eredmények ismertetésénél fogjuk saját munkánkkal összevetni. Az általunk elemzett hazai várostipológiákat - a vizsgálatba bevont városok körével továbbá a vizsgálati szempontokkal - az 1. táblázat mutatja be.

\section{1. táblázat-Table 1}

Hazai várostipológiák a vizsgálatba bevont városok köre, és a vizsgálati szempontok szerint

Hungarian urban typologies and the examined cities and indicators

\begin{tabular}{|c|c|c|c|}
\hline Szerzók & Tipológia & Bevont városok köre & Szempontok \\
\hline $\begin{array}{l}\text { BELUSZKY } \\
\text {-GYŐRI } \\
(1999)\end{array}$ & $\begin{array}{l}\text { - Dinamikusan fejlődő, növekvő } \\
\text { városok } \\
\text { - Mérsékelt dinamikájú városok } \\
\text { - Stagnáló városok } \\
\text { - Pozícióikban visszaeső, stag- } \\
\text { náló - hanyatló városok } \\
\text { - Csökkenő méretű, hanyatló } \\
\text { városok }\end{array}$ & & $\begin{array}{l}\text { - népességszám } \\
\text { - a munkahelyek számá- } \\
\text { nak változása } \\
\text { - a munkanélküliségi ráta } \\
\text { - a gazdasági szervezetek } \\
\text { számának alakulása } \\
\text { - városhierarchiában bekö- } \\
\text { vetkezett változások }\end{array}$ \\
\hline $\begin{array}{l}\text { BELUSZKY } \\
\text {-GYŐRI } \\
(2004)\end{array}$ & $\begin{array}{l}\text { - 1910-ben megyeközpontok, } \\
\text { ma középvárosok } \\
\text { - Mindkét időpontban közép- } \\
\text { városok } \\
\text { - } 1910 \text { óta „felemelkedett” kö- } \\
\text { zépvárosok } \\
\text { - 1910-ben még középvárosok, } \\
\text { ma kisvárosok }\end{array}$ & $\begin{array}{l}\text { harminchat város: } \\
\text { megyeszékhelyek, } \\
\text { közép- és kisvárosok }\end{array}$ & \\
\hline $\begin{array}{l}\text { CSOMÓs } \\
(2016)\end{array}$ & $\begin{array}{l}\text { - Budapest és agglomeráció } \\
\text { - Regionális központok } \\
\text { - Tradicionális iparközpontok } \\
\text { - Idegenforgalmi központok } \\
\text { - Új gazdasági központok } \\
\text { - Offshore települések }\end{array}$ & huszonöt város & $\begin{array}{l}\text { - adózott eredmény } \\
\text { - értékesítés nettó árbe- } \\
\text { vétele export értékesítés } \\
\text { nettó árbevétele } \\
\text { - kibocsátás összesen } \\
\text { - mérlegföösszeg } \\
\text { - saját tőke összege } \\
\text { - bruttó hozzáadott érték } \\
\text { - (településgazdasági súly) }\end{array}$ \\
\hline $\begin{array}{l}\text { EGEDY } \\
(2012)\end{array}$ & $\begin{array}{l}\text { - Válság nyertesei } \\
\text { - Billegók } \\
\text { - Válság vesztesei }\end{array}$ & $\begin{array}{l}\text { tíz nagyváros: } \\
\text { Budapest, Kecskemét, } \\
\text { Győr, Székesfehérvár, } \\
\text { Pécs, Nyíregyháza, } \\
\text { Tatabánya, Szeged, } \\
\text { Debrecen és Miskolc }\end{array}$ & \\
\hline $\begin{array}{l}\text { LENGYEL } \\
- \text { VAS } \\
(2015)\end{array}$ & $\begin{array}{l}\text { - Globális gazdaságba integrá- } \\
\text { lódott településegyüttes } \\
\text { - Multinacionális feldolgozóipa- } \\
\text { ri településegyüttesek } \\
\text { - Nagy egyetemmel bíró telepü- } \\
\text { lésegyüttesek } \\
\text { - Hazai piacra termelő feldolgo- } \\
\text { zóipari településegyüttesek }\end{array}$ & $\begin{array}{l}\text { húsz város } \\
\text { (megyeközpontok } \\
\text { és Budapest) }\end{array}$ & \\
\hline
\end{tabular}




\begin{tabular}{|c|c|c|c|}
\hline Szerzők & Tipológia & $\begin{array}{l}\text { Bevont } \\
\text { városok köre }\end{array}$ & Szempontok \\
\hline $\begin{array}{l}\text { RECHNITZER } \\
\text { et al. (2004) } \\
\text { és } \\
\text { RECHNITZER } \\
\text { et al. (2014) }\end{array}$ & $\begin{array}{l}\text {-6 innovációs } \\
\text { klaszter }\end{array}$ & $\begin{array}{l}\text { huszonárom } \\
\text { innovációs } \\
\text { szempontból } \\
\text { kiugró város }\end{array}$ & $\begin{array}{l}\text { - Gazdasági fókomponens } \\
\text { - gazdasági fejlettség mutatója (62\%-os súrítés) } \\
\text { - Iskolázottság és menedzsment fókomponens } \\
\text { - fejlett munkaerôpiac (79\%-os súrítés) } \\
\text { - Társadalmi aktivitás főkomponens - tudatos } \\
\text { választói magatartás, virulens civil társadalom, } \\
\text { összetett helyi nyilvánosság (60\%-os sưrítés) } \\
\text { - Humánerőforrás-fókomponens } \\
\text { - a felsóokoktatási szféra intézményi- és humán } \\
\text { állományi súlya (62\%-os súrítés) } \\
\text { - Innovációs fő́komponens - az innovációs } \\
\text { intézményhálózat összetettsége és sứrúsége, az } \\
\text { innovációs potenciál mértéke (82\%-os súrítés) }\end{array}$ \\
\hline $\begin{array}{l}\text { MAKRA } \\
\text {-SÜMEGHY } \\
(2010)\end{array}$ & $\begin{array}{l}\text { - } 6 \text { klaszter a } \\
\text { Green Cities } \\
\text { Index } \\
\text { és a Green } \\
\text { Counties } \\
\text { Index alapján }\end{array}$ & $\begin{array}{l}\text { nyolcvannyolc } \\
\text { magyar város }\end{array}$ & $\begin{array}{l}\text { - vízfogyasztás } \\
\text { - energiafogyasztás } \\
\text { - közmú-ellátottság } \\
\text { - közlekedés } \\
\text { - hulladékkezelés } \\
\text { - települési kényelmi tényező́k } \\
\text { - levegóminőség }\end{array}$ \\
\hline
\end{tabular}

Forrás/Source: Saját szerkesztés / Authors’ editing

\section{Kutatási kérdések és módszertan}

Kutatásunk célja volt, hogy infrastrukturális, gazdasági és társadalmi-kulturális jellemzőik alapján, induktív módon elkészítsük a magyarországi közép- és nagyvárosok versenyképességi tipológiáját humán tőke vonzó potenciáljuk bázisán, majd az elkülönített várostípusok viselkedését további változók alapján mutassuk be. A vizsgált települések körét Magyarország közép- és nagyvárosai alkották. Kutatásunkban a hazánkban a népességszám alapján kialakult települési hierarchiát figyelembe véve alakítottuk ki a közép- és nagyvárosok kategóriáját, amely alapján e várostípusba tartozónak tekintjük a húszezer főnél népesebb, de az egymilliós lélekszámot meg nem haladó településeket. A kutatás céljának eléréséhez, illetve az elemzési kérdésünk megválaszolásához három lépcsőben elemeztük a vizsgált magyarországi városok társadalmi-gazdasági jellemzőit.

A szakirodalom által leírt indikátorokat, valamint javaslatokat (NEMES-NAGY J. 2007; GYURIS F. 2014) felhasználva meghatároztuk azokat a változókat, amelyekkel az egyes szempontokat megfeleló módon ragadhatjuk meg - különös tekintettel a magasan képzett munkaeró vonzására. E réteg a versenyképesség tekintetében már az 1960-as évektól kezdve kiugró szerepet kapott, hiszen egy-egy település fenntartható növekedését hosszútávon - természetesen nem kizárólagosan - képes biztosítani. A humán tőke szerepéről folytatott tudományos vitákban GLAESER, E. L.-BERRY, C. L. (2005) a képzett lakosság arányát, mint települési sikertényezőt azonosította, GRANOVETTER, M. (1977) a gyenge és erős kötések, a társadalmi háló szerepét hangsúlyozta. BourdiEu, P. (1989) és PUTNAM, R. (1995) társadalmi bizalmat igyekezett megragadni, míg FLORIDA, R. (2002) ezek mellett a technológiai fejlődés, a tehetséges, kreatív munkaerő, illetve a társadalmi befogadás, tolerancia mértékét emelte ki.

Modellünk Magyarország-specifikusságának biztosítása érdekében a módszertan validálása négy fókuszcsoportos vizsgálatra épül. A vizsgálatba bevont indikátorok körének 
kiválasztási bázisát adta, hogy a versenyképességi irányultságú várostipológiák számos esetben csupán gazdasági, kemény mutatókat tartalmaznak, figyelmen kívül hagyva a versenyképesség 21. századi, egyre inkább ember- és kultúraközpontú megközelítését. Ennek szem előtt tartásával, a vizsgálatba beemelt egyes változók a hivatalos társadalmi-gazdasági statisztikai adatok mellett olyan BigData jellegú puha elemeket is tartalmaznak, melyek a tipológia újszerúségét adják, s amelyeket a rendelkezésre álló információforrások alapján magunk számoltunk. A vizsgálat második lépéseként főkomponens elemzéssel csoportosítottuk a változókat annak érdekében, hogy a mérhetôvé tett szempontokat a városok helyzetének egy-egy átfogóbb aspektusára általánosítva kapjuk meg. Ehhez a harmadik lépés, nevezetesen a településtipológia meghatározásához volt szükség, amelyet klaszterelemzéssel végeztünk. (A múveletek elvégzéséhez az IBM SPSS Statistics 19.0 verziójának algoritmusait használtuk.)

A főkomponenselemzéshez négy dimenziót különítettünk el, amelyhez egy-egy, egymással átfedésben nem lévő változószettet különítettünk el. A négy említett dimenziót 1) az alapinfrastruktúra (közlekedési és lakásinfrastruktúra), 2) a szolgáltatásgazdagság (kereskedelem, vendéglátás, szabadidő), 3) a munkaerőpiac (for- és nonprofit szervezetek, álláslehetőségek továbbá jövedelem), illetve 4) az információs társadalom (oktatás, kutatás, kommunikáció) jelentették. A főkomponenseket a 2. táblázatban rögzített változók alapján hoztuk létre.

2. táblázat-Table 2

Az alkalmazott főkomponensek, a fókomponensben foglalt változók és adatforrásaik Principal components, the included indicators and data sources of them

\begin{tabular}{|c|c|c|}
\hline $\begin{array}{l}\text { Fókomponens } \\
\text { megnevezése }\end{array}$ & Foókomponensben foglalt változók & Adatforrás \\
\hline \multirow[t]{5}{*}{$\begin{array}{l}\text { Alap- } \\
\text { infrastruktúra }\end{array}$} & $\begin{array}{l}\text { 2012-2017 között épített („,újépítésú”) lakások aránya } \\
\text { az 2017-es lakásállományból }\end{array}$ & KSH \\
\hline & $\begin{array}{l}\text { Átlagos ingatlan bérleti ár/m² reciproka (1/bérleti ár) } \\
\text { (2017 utolsó havi átlag) }\end{array}$ & ingatlannet.hu \\
\hline & $\begin{array}{l}\text { ezer főre jutó személygépkocsik száma az üzemeltető } \\
\text { lakhelye szerint reciproka (2017) }\end{array}$ & KSH \\
\hline & $\begin{array}{l}\text { Budapesti vagy bécsi nemzetközi repülőtér elérhetősége } \\
\text { autóval (perc) nyolc munkaórára vetítve (reciprok) } \\
\text { (1/Elérhetőség percben/480) (2019) }\end{array}$ & $\begin{array}{l}\text { saját számítás } \\
\text { maps.google.com } \\
\text { alapján }\end{array}$ \\
\hline & $\begin{array}{l}\text { Önkormányzati kerékpárút, közös gyalog- és kerékpárút } \\
\text { hossza az önkormányzati és állami kiépített út és köztér } \\
\text { arányában (2017) }\end{array}$ & $\mathrm{KSH}$ \\
\hline \multirow[t]{7}{*}{$\begin{array}{l}\text { Szolgáltatás- } \\
\text { gazdagság }\end{array}$} & $\begin{array}{l}\text { Bevásárlóközpontok és hipermarketek száma a lakónépesség } \\
\text { arányában (2017) }\end{array}$ & $\mathrm{KSH}$ \\
\hline & Múzeum és színházlátogatók ezer fó népességre vetítve (2017) & $\mathrm{KSH}$ \\
\hline & Büfék száma a népesség arányában ezer főre vetítve (2017) & $\mathrm{KSH}$ \\
\hline & Google-ön 4,5 felett értékelt kávézók száma (2019) & $\begin{array}{l}\text { saját számítás } \\
\text { maps.google.com } \\
\text { alapján }\end{array}$ \\
\hline & Google-ön 4,5 felett értékelt éttermek száma (2019) & $\begin{array}{l}\text { saját számítás } \\
\text { maps.google.com } \\
\text { alapján }\end{array}$ \\
\hline & $\begin{array}{l}\text { Regisztrált (társas) vállalkozások száma a szálláshely- } \\
\text { szolgáltatás, vendéglátás nemzetgazdasági ágban } \\
\text { a lakónépesség arányában ezer fő́re vetítve (2017) }\end{array}$ & $\mathrm{KSH}$ \\
\hline & $\begin{array}{l}\text { Regisztrált (társas) vállalkozások száma a múvészet, } \\
\text { szórakoztatás, szabadidó nemzetgazdasági ágban a népesség } \\
\text { arányában (2017) }\end{array}$ & $\mathrm{KSH}$ \\
\hline
\end{tabular}




\begin{tabular}{|c|c|c|}
\hline $\begin{array}{l}\text { Fókomponens } \\
\text { megnevezése }\end{array}$ & Fő́komponensben foglalt változók & Adatforrás \\
\hline \multirow[t]{4}{*}{$\begin{array}{l}\text { Munkaeró- } \\
\text { piac }\end{array}$} & $\begin{array}{l}\text { Múkködő vállalkozások száma a népesség arányában ezer főre } \\
\text { vetítve (2016) }\end{array}$ & $\mathrm{KSH}$ \\
\hline & $\begin{array}{l}\text { Egyetemi végzettségú, egy-három év munkatapasztalattal } \\
\text { rendelkező munkavállalóknak kínált állások száma } \\
\text { a lakónépesség arányában (2019) }\end{array}$ & profession.hu \\
\hline & Összes belföldi jövedelem ezer adózóra vetítve (2017) & NAV \\
\hline & Nonprofit és civil szervezetek száma lakosságra vetítve (2017) & $\mathrm{KSH}$ \\
\hline \multirow[t]{6}{*}{$\begin{array}{l}\text { Információs } \\
\text { társadalom }\end{array}$} & $\begin{array}{l}\text { Regisztrált vállalkozások száma az oktatás nemzetgazdasági } \\
\text { ágban az összes vállalkozás arányában (2017) }\end{array}$ & $\mathrm{KSH}$ \\
\hline & $\begin{array}{l}\text { Helyi egyetem(ek) által elnyert EU-s pályázati források ezer } \\
\text { fóre vetítve (2014-2017 időszak) }\end{array}$ & palyazat.gov.hu \\
\hline & $\begin{array}{l}\text { Gyarapodó tudástőkére fordított EU-s források, ezer főre } \\
\text { vetítve (2014-2017) }\end{array}$ & palyazat.gov.hu \\
\hline & $\begin{array}{l}\text { Regisztrált vállalkozások száma a szakmai, tudományos, } \\
\text { múszaki tevékenység nemzetgazdasági ágban az összes } \\
\text { regisztrált vállalkozás arányában (2017) }\end{array}$ & $\mathrm{KSH}$ \\
\hline & $\begin{array}{l}\text { Regisztrált vállalkozások száma az információ, kommunikáció } \\
\text { nemzetgazdasági ágban összes vállalkozás arányában (2017) }\end{array}$ & $\mathrm{KSH}$ \\
\hline & Internet előfizetések száma ezer főre vetítve (2017) & KSH \\
\hline
\end{tabular}

Forrás/Source: Saját szerkesztés / Authors' editing

Fontos felhívni a figyelmet módszertanunk korlátaira: a statisztikai adatgyújtésben viszonylag kevés az olyan jellegú információ, amivel a települések területi tőkéje, sikeressége a 21. századi, emberközpontú értelmezésnek megfelelően mérhető lenne. Azonban a puha mutatók bevonása az elemzésbe megbízhatatlanságot, az érvényesség csökkenését is jelentheti, miközben ez lehet a módszer egyik fó erénye. Szintén fontos megemlíteni, hogy elemzésünk csak kvantitatív elemekre támaszkodik, így ennek eredményeit tovább árnyalhatja kvalitatív adatfelvétel, esettanulmányi feldolgozás.

A fókomponenselemzés során az egyes dimenziókat több változóval kívántuk megragadni, az adatredukciós módszer során azonban ezek körében egyesek különutasnak bizonyultak. Minthogy az egyes dimenziók e változók nélkül is jól magyarázhatók voltak, továbbá, a késóbbi klaszterelemzés során minél kevesebb dimenzióval (változókként értelmezett fókomponensekkel) kívántunk dolgozni, a különutas változókat kihagytuk elemzésünkből. A végleges változók csoportjai alapján futtatott főkomponenselemzés eredményesnek bizonyult. Az egyes változószettek változóinak megfeleltethetőségét tesztelő KMO-vizsgálat a közepes megfelelőségi kategóriába tartozó eredményeket mutatott. A változók összesített eredeti információtartalmának az egyes fókomponensek a 3. táblázatban rögzített

KMO és megmagyarázott hányad

$\mathrm{KMO}$ and explained proportion

\begin{tabular}{ccc}
\hline & KMO érték & Megmagyarázott hányad \\
\hline FAC1 & 0,658 & 0,428 \\
FAC2 & 0,782 & 0,545 \\
FAC3 & 0,643 & 0,658 \\
FAC4 & 0,626 & 0,508 \\
\hline
\end{tabular}

Forrás/Source: Saját szerkesztés / Authors' editing 
százalékát őrizték meg. Mindezekkel a kapott főkomponenseket alkalmasnak tekinthettük arra, hogy az eredeti elképzelésünknek megfeleltethető egyes gazdasági-társadalmi dimenziókat egyetlen mérőszámmal ragadhassuk meg a vizsgált ötvennyolc közép- és nagyváros vonatkozásában.

\section{Kutatási eredmények}

A kapott főkomponensek segítségével ezután csoportokba foglaltuk az 58 magyarországi közép- és nagyvárost (1. ábra). Ennek során a csoportosításra hierarchikus klaszterelemzési eljárást (euklédeszi távolságokon alapuló within-groups linkage módszer) alkalmaztunk, melynek kiválasztását az elemzés induktív módszertana továbbá a kis elemszám

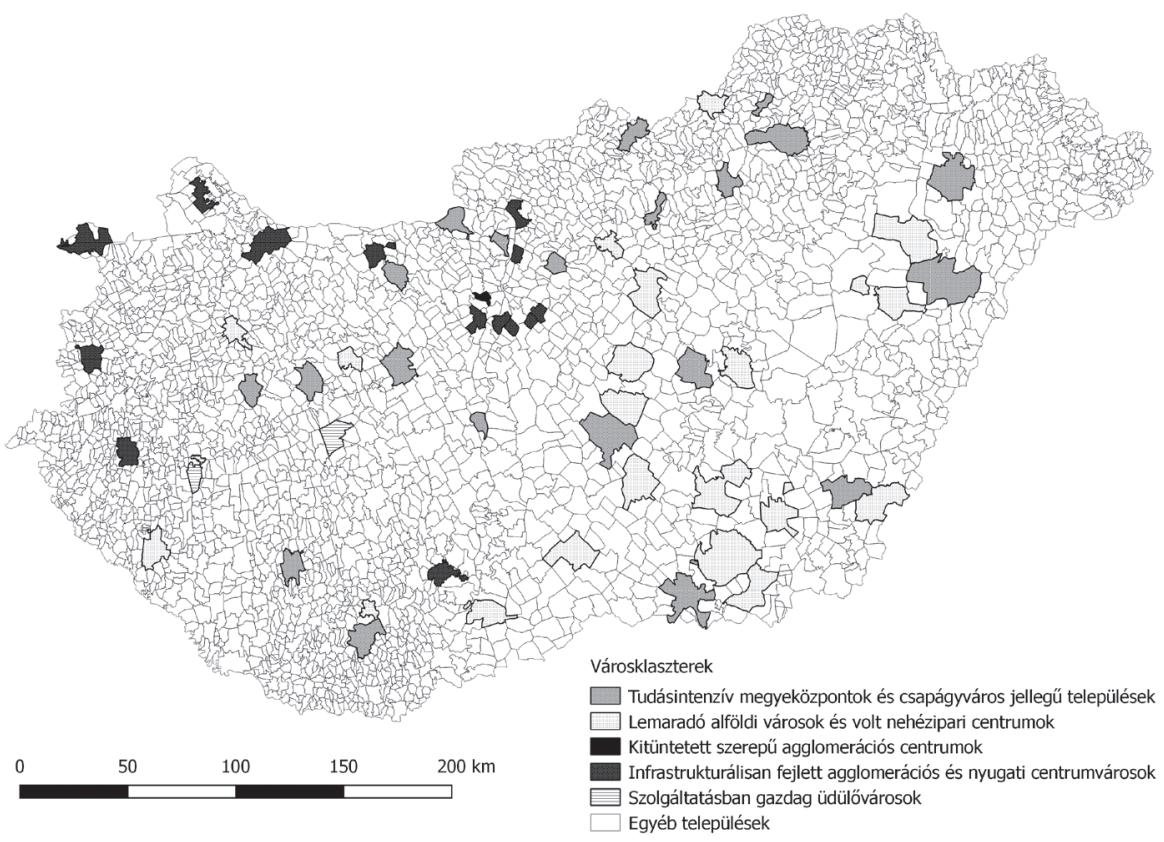

1. ábra Az egyes klaszterekhez tartozó városok elhelyezkedése közigazgatási határaik alapján lehatárolva Saját szerkesztés

Figure 1 Location of cities belonging to each cluster delimited according to their administrative boundaries Authors' editing

indokolja. A klaszterezési eljárás dendogramja alapján összesen öt klaszter (városcsoport) megkülönböztetése mellett döntöttünk, amelyek megfelelő módon elkülöníthetôk mindemellett jól interpretálhatók. A két legfóbb klasztert, amelyek együttesen a vizsgált városok kétharmadát tartalmazzák, a „tudásintenzív megyeközpontok és csapágyváros jellegü települések” ( $\mathrm{n}=21)$, illetve „,lemaradó alföldi városok és volt nehézipari centrumokok” $(\mathrm{n}=20)$ címkékkel illethetünk. Az ,infrastrukturálisan fejlett agglomerációs és nyugati centrumvárosok" képezik a harmadik legnagyobb, az összes eset negyedét $(n=14)$ magába foglaló klasztert, míg a két legkisebb klaszterbe kettő, illetve egy darab város tartozik. Ezek elkülönítése azért fontos, mert a faktorértékek alapján értelmezett viselkedésüket tekintve a többihez képest jelentősen eltérnek. A klaszterhovatartozást a 4. táblázat szemlélteti. 
Az egyes klaszterekhez tartozó városok

Cluster membership of the examined cities

\begin{tabular}{|c|c|c|c|c|}
\hline $\begin{array}{c}\text { 1. klaszter } \\
\text { szolgáltatásban } \\
\text { gazdag } \\
\text { üdülóvárosok }\end{array}$ & $\begin{array}{c}\text { 2. klaszter } \\
\text { tudásintenzív } \\
\text { megyeközpontok } \\
\text { és csapágyváros } \\
\text { jellegü települések }\end{array}$ & $\begin{array}{c}\text { 3. klaszter } \\
\text { infrastrukturálisan } \\
\text { fejlett agglomerációs } \\
\text { és nyugati } \\
\text { centrumvárosok }\end{array}$ & $\begin{array}{l}\text { 3. klaszter } \\
\text { lemaradó alföldi } \\
\text { városok és volt } \\
\text { nehézipari } \\
\text { centrumok }\end{array}$ & $\begin{array}{c}\text { 5. klaszter } \\
\text { kitüntetett } \\
\text { szerepü } \\
\text { agglomerációs } \\
\text { centrum }\end{array}$ \\
\hline $\begin{array}{l}\text { Keszthely } \\
\text { Siófok }\end{array}$ & $\begin{array}{l}\text { Ajka } \\
\text { Békéscsaba } \\
\text { Debrecen } \\
\text { Dunaújváros } \\
\text { Esztergom } \\
\text { Gyöngyös } \\
\text { Kaposvár } \\
\text { Kazincbarcika } \\
\text { Kecskemét } \\
\text { Miskolc } \\
\text { Nyíregyháza } \\
\text { Pécs } \\
\text { Salgótarján } \\
\text { Szeged } \\
\text { Székesfehérvár } \\
\text { Szolnok } \\
\text { Tatabánya } \\
\text { Eger } \\
\text { Veszprém } \\
\text { Gödöllő } \\
\text { Szentendre }\end{array}$ & $\begin{array}{l}\text { Dunaharaszti } \\
\text { Dunakeszi } \\
\text { Érd } \\
\text { Gyál } \\
\text { Győr } \\
\text { Mosonmagyaróvár } \\
\text { Sopron } \\
\text { Szekszárd } \\
\text { Szigetszentmiklós } \\
\text { Tata } \\
\text { Vecsés } \\
\text { Szombathely } \\
\text { Vác } \\
\text { Zalaegerszeg }\end{array}$ & $\begin{array}{l}\text { Baja } \\
\text { Cegléd } \\
\text { Gyula } \\
\text { Hajdúböszörmény } \\
\text { Hajdúszoboszló } \\
\text { Hatvan } \\
\text { Hódmezóvásárhely } \\
\text { Jászberény } \\
\text { Kiskunfélegyháza } \\
\text { Kiskunhalas } \\
\text { Komló } \\
\text { Makó } \\
\text { Nagykanizsa } \\
\text { Nagykőrös } \\
\text { Orosháza } \\
\text { Ózd } \\
\text { Pápa } \\
\text { Szentes } \\
\text { Törökszentmiklós } \\
\text { Várpalota }\end{array}$ & Budaörs \\
\hline
\end{tabular}

Forrás/Source: Saját szerkesztés / Authors' editing

Ahogy a 2.ábrán is látható, a „tudásintenzív megyeközpontok és csapágyváros jellegü települések" klaszterre viszonylag alacsony infrastrukturális ellátottság és szolgáltatásgazdagság jellemző, amelyet azonban ellensúlyoz a kedvezőbb munkaerôpiaci helyzetkép, illetve a rendkívül magas információs társadalmi értékek, amelyek elsôsorban az egyetemek jelenlétével magyarázhatóak. A klaszter elnevezésével kapcsolatban azonban fontos a „csapágy város” fogalmát tisztázni - illetve, hogy e cikk pontosan milyen városkört és funkciókat ért az elnevezés alatt. A budapesti metropolisztérség határán elhelyezkedő, ötvenszázezer fő lakónépességú városok gyûrüjét (Székesfehérvár, Dunaújváros, Kecskemét, Szolnok, Hatvan, Salgótarján, Esztergom, Tatabánya), melyek mintegy hatvan-nyolcvan km sugarú kört leírva helyezkednek el a fóváros körül, csapágyvárosoknak nevezzük az Országos Fejlesztési és Területfejlesztési Koncepció (OFTK) 2014-ben megjelent változata szerint. A kör észak-nyugati, Szlovákiába eső, korábban Magyarország részét képező szektora történelmi okokból hiányzik. E városok sajátossága - amellett, hogy befektetési helyszínt jelentenek a gépkocsigyártás és -összeszerelés, az IT és a logisztika, valamint a $\mathrm{K}+\mathrm{F}$ területén a külföldi tőke számára-, hogy egyfajta közvetítővárosi szereppel is bírnak, mely által a globális trendeket, termelési módokat és szervezeti-múködési formákat képesek átadni közvetlen vonzáskörzetüknek, becsatornázva ezáltal a periferikus területeket a globális termelési körökbe. Bár a klaszterbe került városok közül néhány (pl.: a Gödöllő-Szentendre páros, vagy Ajka és Kazincbarcika) nem tekinthető klasszikus értelemben vett csapágyvárosnak, hasonlóságokat mutat e városkörrel abban az értelemben, hogy 


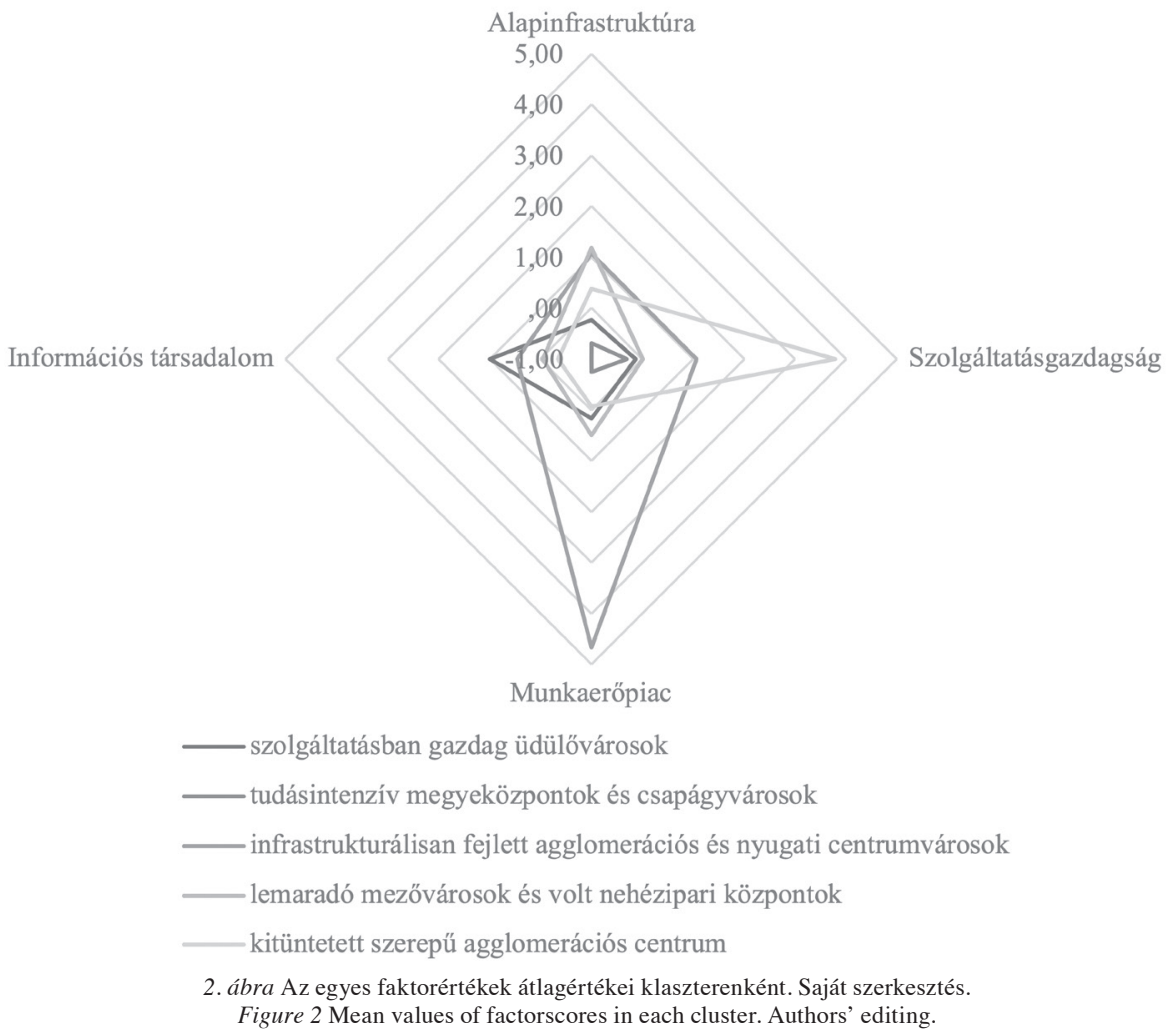

fejlődése a főváros és agglomerációja relációjában értelmezhető, az ezekkel való együttmúködés alapvetóen meghatározza a települések sikerességét. A klaszterbe került városokról elmondható, hogy az információs társadalom faktoron mért magas értékek ellenére született néhány kiugróan alacsony eredmény, melynek oka, hogy az érintett településeken nincs jelen a felsőoktatás. Szentendre és Eger több szempontból kiemelkedik - leginkább a szolgáltatásgazdagság terén. Kazincbarcika több ízben nyújt kiugróan alacsony eredményt, amelynek oka az egyetemi forrásfelhasználás hiánya továbbá az alacsony számú múzeumlátogató.

Az ,infrastrukturálisan fejlett agglomerációs és nyugati centrumvárosok” klaszter (vagyis azok a városok, amelyek Budapest vonzáskörzetében, vagy a nyugati országrészben helyezkednek el), nagy részük elsősorban épp területi elhelyezkedésük miatt rendelkeznek kitűnő infrastrukturális adottságokkal, a munkaerőpiaci helyzetképük rendkívül kedvező, míg szolgáltatásgazdagságukra épp a főváros közelsége lehet negatívabb hatással, ez összességében a középmezőnybe sorolja ezeket a településeket. Információs társadalmi értéküket tekintve szintén köztes helyet foglalnak el, amely azzal függhet össze, hogy ezen településeken nincs jelen a felsőoktatás. Az agglomerációs városok közül az ezer adózóra jutó belföldi jövedelem mértéke alapján Dunakeszi emelkedik ki, míg a nyugati centrumvárosok közül az osztrák határhoz, valamint Bécshez és Pozsonyhoz közeli, stratégiai elhelyezkedésú Mosonmagyaróvár említendő, ahol különösen magas az újépítésú lakások aránya. Érd, Gyál továbbá Vecsés klaszterhovatartozását inkább Budapest közelsége, mint általánosan előnyös területi elhelyezkedésük indokolja, ezek a települések rendelkeznek a legkedvezőtlenebb értékekkel a klaszteren belül. 
A ,lemaradó alföldi városok és volt nehézipari centrumok” klaszter tagjai ezzel szemben egységesen rendkívül kedvezőtlen helyzetben vannak valamennyi vizsgált változóból képzett csoportot tekintve. Alapinfrastruktúra tekintetében rendelkeznek néhány jó eredménnyel a lakásbérleti árak (Komló), az egy főre jutó autók száma (Ózd) valamint az önkormányzati kerékpárút, közös gyalog- és kerékpárút arányát (Hódmezővásárhely) nézve. Az említett indikátorokban a kiemelkedés önmagában - értelemszerúen - nem előnyt jelent, hanem kifejezetten az elmaradott települések jellemzője. A klaszternek minden faktor esetében vannak mélypontjai, a legtöbb a digitális társadalom esetében. A legtöbb alacsony eredmény Ózdhoz, Hajdúböszörményhez továbbá Ceglédhez kapcsolható.

A klaszterelemzés eredményeképpen létrejött öt klaszter közül két csoport alacsony elemszámú: a „szolgáltatásban gazdag üdülóvárosok” és a „,kitüntetett szerepü agglomerációs centrum”. A „szolgáltatásban gazdag üdülővárosok” arányított szolgáltatásgazdagságukat tekintve előzik meg a teljes mezónyt - ideértve a „, kitüntetett szerepú agglomerációs centrumot” is -, valójában csupán a múzeumlátogatók és a múvészeti profilú vállalkozások tekintetében nem értek el maximum értéket ezen a faktoron. Ellenben munkaerôpiaci továbbá információs társadalmi mutatóikat tekintve kedvezőtlen helyzetûnek tekinthetőek. Két Balaton-melletti város, Siófok, valamint Keszthely alkotja ezt a csoportot. Egy kiugróan alacsony értékkel találkozunk a klaszter esetében, a munkahelyek tekintetében, Keszthelyen ugyanis nem található a magasan képzett munkavállalóknak meghirdetett állás.

Végül, a „kitüntetett szerepú agglomerációs centrum” kategóriájában egyedül Budaörs szerepel, amelyet az adatok tekintetében sem véletlenül szokás Budapest XXIV. kerületének tartani. A város egységesen, minden mutató tekintetében az élmezőnybe tartozik. Munkaerőpiaci tekintetben a vizsgált elemek közül ez a település rendelkezett a legtöbb működő vállalkozással, valamint magasan képzett munkaerő számára kínált állással népességarányosan. A további faktorokat tekintve viszont egy-egy klaszter rendre lekörözi (infrastruktúráját tekintve kevéssel az infrastrukturálisan fejlett agglomerációs és nyugati centrumvárosok, míg információs társadalmi mutatója tekintetében a tudásintenzív megyeközpontok és csapágyváros jellegü települések jócskán). Budaörsnek nincs felsőoktatási intézménye, ezért kapott az ehhez kapcsolódó mutatók terén nulla értéket. Az autók száma - amelyet a változók értékelésénél negatívumként értelmeztünk az ingázáshoz és környezetterheléshez való kapcsolódása miatt - viszont rendkívül magas. A klaszterek faktorértékenként vett eredményeit az 1. ábra összesíti.

\section{Hasonlóságok és különbségek a korábbi várostipológiákkal}

Jelen kutatáshoz hasonló elemzéseket végzett TóTH B. I. (2011), LENGYEL I. - VAS Zs. (2015) és Csomós Gy. (2016) is. Tótн B. I. (2011) kutatásában ötvenkét magyar közép- és nagyváros összehasonlítására kerül sor - a bevont városok köre majdnem azonos a jelen tanulmányban kutatott ötvennyolc magyar közép- és nagyvárossal, illetve a bevont változók köre is összehasonlítható. Tóтн B. I. (2011) - a területi tőke vizsgálata érdekében elsősorban gazdasági fejlettséget mérő változókat vont be a kutatásába, amelyeket az alábbi dimenziókba kategorizálta: (1) a település vállalkozásainak jellemzői, (2) a település környezetének jellemzői, (3) a települési szolgáltatások jellemzői, (4) a települési közmúvelődés, valamint tudáserőforrás jellemzői, (5) a település társadalmának jellemzői, illetve (6) a település attraktivitásának jellemzői. Hasonlóan, a vizsgált városok öt klaszterét különböztette meg, amelyek közül három klasztere jelentős átfedést mutat jelen kutatás három nagy elemszámú klaszterével, tehát a „,,tudásintenzív megyeközpontok és csapágy- 
város jellegü települések” (azonos klaszterben szerepel: Ajka, Békéscsaba, Esztergom, Szentendre, Szolnok), az „infrastrukturálisan fejlett agglomerációs és nyugati centrumvárosok" (azonos klaszterben szerepel: Szigetszentmiklós, Vecsés, Dunaharaszti, Gyál, Dunakeszi, Érd) továbbá a „lemaradó alföldi városok és volt nehézipari centrumok” (azonos klaszterben szerepel: Cegléd, Hajdúböszörmény, Hajdúszoboszló, Hódmezővásárhely, Kiskunfélegyháza, Makó, Nagykőrös, Orosháza) klaszterekkel.

A megyeközpontok Budapesttel való összehasonlító elemzésére vállalkozott LENGYEL I. - VAS Zs. (2015) kutatása, amelynek eredményeként a magyar városok négy fó klaszterét vázolják fel: globális gazdaságba integrálódott településegyütteseket (Budapest és környéke), multinacionális feldolgozóipari településegyütteseket (Győr, Székesfehérvár, Tatabánya, Szombathely, Kecskemét), nagy egyetemmel bíró településegyütteseket (Debrecen, Miskolc, Pécs, Szeged, Veszprém) valamint hazai piacra termelő feldolgozóipari településegyütteseket különböztetnek meg. LENGYEL I.-VAS Zs. (2015) kutatása húsz magyar várostérségre (településegyüttesre) és nem a közigazgatási határokon belül értelmezett városokra fókuszál, tehát szembetűnő együttállást csak a „nagy egyetemmel bíró településegyüttesek” klaszterének tagjai, valamint jelen kutatás „,tudásintenzív megyeközpontok és csapágyváros jellegú települések" csoportja között figyelhetünk meg.

TóTH B. I. (2011) továbbá LENGYEL I. - VAS Zs. (2015) kutatásához hasonlóan Csomós Gy. (2016) is a hazai városok, mint gazdasági központok egymáshoz viszonyított pozícióit elemezte egy általa kidolgozott, településgazdasági súlynak nevezett komplex mutató alapján. Csomós Gy. (2016) a vizsgált huszonöt várost hat klaszterbe csoportosítja: míg a Budapest és agglomerációja (Budaörs, Szentendre, Törökbálint, Érd, Szigetszentmiklós), illetve a regionális központok szinte a legtöbb ilyen vizsgálatban elkülönülnek, itt külön klasztert alkotnak a tradicionális ipari központok mellett az új gazdasági központok (Komárom, Jászfényszaru, Esztergom, Hatvan, Tab, Rácalmás, Bicske, Szentgotthárd), az idegenforgalmi központok (Balaton-környéki települések) és az alacsony iparúzési adót kínáló „offshore” települések (Szombathely, Újlengyel, Csomád) is. Jelen kutatással egyértelmú összehangot láthatunk a „szolgáltatásban gazdag üdülóközpontok” esetében.

Összességében elmondható, hogy kutatásunk három nagy elemszámú klaszterének tagjai az elmúlt évek hasonló módszertanú magyarországi kutatásaiban hasonlóképp csoportosulnak klaszterekbe. Ezzel szemben a kicsi, egy-két elemszámú klaszterek azok, amelyek a változók körétől függően különböző módon különülnek el: míg a jelen kutatásban a kiemelkedő gazdasági tevékenység mellett magas iparüzési adóval rendelkező Budaörs, illetve a Balaton közelsége miatt speciális helyzetú Siófok és Keszthely emelkedett ki, addig Csomós Gy. (2016) kutatásában az offshore településeknek nevezett magyar adóparadicsomok (pl. Csomád, Újlengyel) jellemezhetők nagyon kiugró adatokkal.

\section{Diszkusszió}

A városklasztereket a fentiek értelmében gazdasági-társadalmi-kulturális jellemzőik és szolgáltatásaik alapján hoztuk létre, ezek körében demográfiai jellemzőket nem szerepeltettünk. A hiátusokkal leírható magyarországi településszerkezet megértéséhez azonban nélkülözhetetlen feltárni a gazdasági különbségek demográfiai, továbbá a képzettséget, valamint foglalkoztatottságot leíró tényezőkkel való interakcióját. Amennyiben összevetjük a klaszterhovatartozás összefüggését a klaszterhez tartozó településeken élő húsz-harminckilenc éves népesség lakónépességi arányával, a diplomások arányával, továbbá a helyben dolgozók és az összes foglalkoztatott hányadosával, végül a települések lakónépességének számával, az 5. táblázatban rögzített eredményre juthatunk. 
Klaszterhovatartozás összefüggése a településeken élő 20-39 éves népesség lakónépességi arányával, a diplomások arányával, a helyben dolgozók és az összes foglalkoztatott hányadosával és a lakónépességgel

Relationship of cluster membership with: the proportion of the population aged 20-39

from resident population; the proportion of the graduates from resident population; the ratio of the locally employed to the total employed; and the residential population

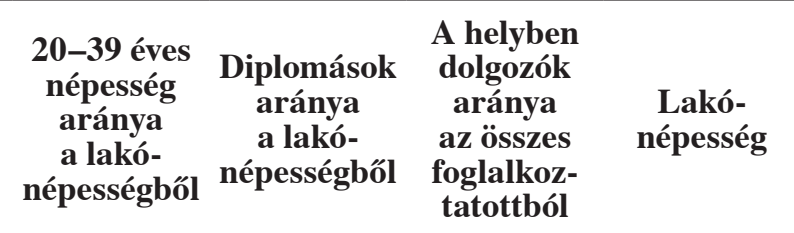

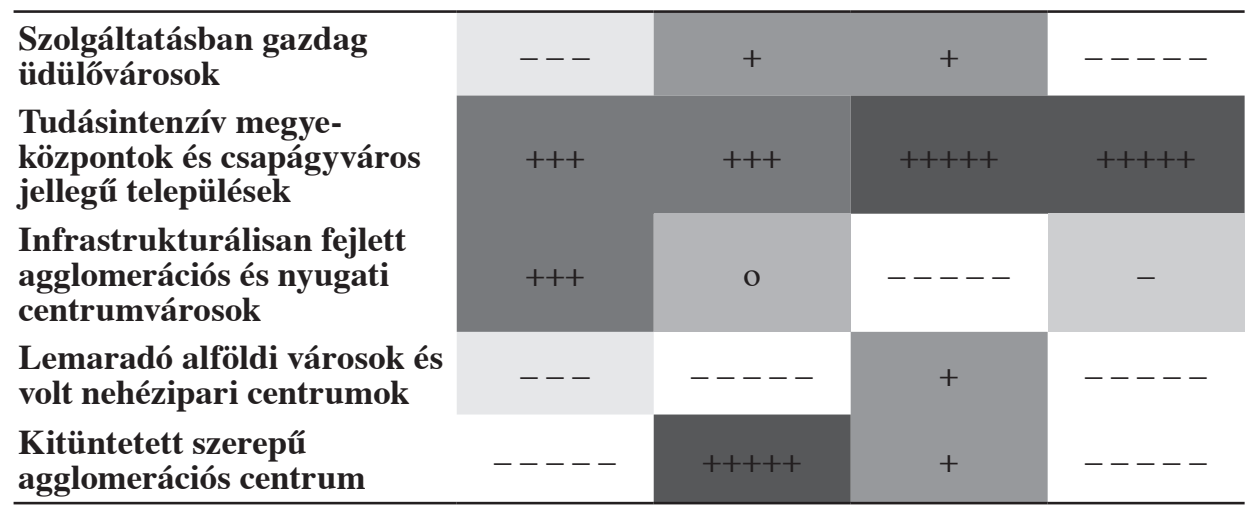

Forrás/Source: Saját szerkesztés / Authors' editing

Jelmagyarázat: ----- : erősen mintaátlag alatti; --- : közepesen mintaátlag alatti; - : kissé mintaátlag alatti; o : mintaátlagnak megfelelő; + : kissé mintaátlag feletti; +++ : közepesen mintaátlag feletti; +++++ : erősen mintaátlag feletti

Az 5. táblázatban összefoglalt kapcsolatok a „, szolgáltatásban gazdag üdülóvárosok” esetében azt mutathatják, hogy a nemzetközi, valamint „magasabb igényszintet kielégíto” turizmus terén a felsőfokú végzettséggel rendelkezők akár helyben is képesek munkát találni. A „tudásintenzív megyeközpontok és csapágyváros jellegü települések” minden vizsgált kategóriában mintaátlag feletti eredményt mutattak, mely összefüggésben állhat a térség endogén fejlődési potenciáljával, az információs társadalom faktoron elért eredményével - látható az egyetemvárosok húzóereje mellett Budapest túlcsorduló hatása is. Fontos megemlíteni továbbá, hogy e klaszterhez tartoztak az átlagosan legnagyobb népességgel rendelkező városok, mely arra enged következtetni, hogy a települési sikeresség és a város mérete kölcsönhatásban van egymással.

Az „infrastrukturálisan fejlett agglomerációs és nyugati centrumvárosok” klaszter tagjai egyaránt érzékelhetik Budapest mellett Bécs „elszívó” hatását is. A „lemaradó alföldi városok és volt nehézipari centrumok” városai a szelektív vándorlás jelenségét tapasztalják, melynek következtében a diplomás munkaerő elvándorol, s helyben marad egy alacsonya(bba)n képzett, kevésbé mobil réteg, melynek tagjai a térségen kívül kisebb eséllyel tudnának elhelyezkedni. E klaszter esetében szintén érdemes kiemelni a lakónépesség számával való összefüggést. 
A „kitüntetett szerepü agglomerációs centrum” egyetlen városa, Budaörs különutas agglomerációs településnek tekinthető: itt kevésbé a fóváros elszívó, inkább „túlcsorduló” hatása érvényesül, számos nagyvállalat helyezi - épp a fóváros közelsége miatt - ide telephelyét, (felsőfokú képzettséget igénylő) munkát biztosítva ezzel a helyiek számára. A városban növekvő ingatlanbérleti és vételi árak miatt azonban a húsz-harminckilenc éves réteg kevésbé engedheti meg magának a beköltözést, így a város inkább a középkorú, magasan képzett, jómódú családok alternatívája.

\section{Összefoglalás}

A kutatás során célunk az volt, hogy infrastrukturális, valamint gazdasági-társadalmikulturális jellemzőik alapján, induktív módon elkészítsük a magyarországi közép-és nagyvárosok versenyképességi tipológiáját, majd az elkülönített várostípusok viselkedését további változók alapján mutassuk be.

A kutatás során kirajzolódott, hogy a klaszterbe sorolásánál a vártnál még nagyobb térszerkezeti hatása van Budapestnek és agglomerációjának. Ez jól látható abból, hogy a Budapest közvetlen környezetében fekvő agglomerációs, közép- és nagyvárosok fejlettségükben felveszik a versenyt a hagyományosan fejlett, nyugati határhoz közeli centrumvárosokkal. Hasonlóan, a Budapest környéki csapágyvárosok méretükhöz, valamint gazdasági-társadalmi múltjukhoz képest szintén megközelítik, vagy akár túllépik a történelmi regionális központok fejlettségi szintjét.

Az elemzés egyértelmúen rávilágított Magyarország kelet-nyugat irányú megosztottságára is, ahogy az 1. ábra is mutatja. Érdekes a „lemaradó alföldi városok és volt nehézipari központok” továbbá a „infrastrukturálisan fejlett agglomerációs és nyugati centrumvárosok" klaszterek tagjainak térbeli elhelyezkedését megfigyelni. Az első klaszter húsz településéből tizenöt alföldi, és a fennmaradó öt dunántúli település közül is három nehézipari múltú (Komló, Ózd, Várpalota), míg kettő stagnáló, de inkább belső perifériának számító feldolgozóipari múltú (Nagykanizsa, Pápa). Ezzel szemben a második említett klaszter tizennégy települése kivétel nélkül dunántúli (hét db) vagy Budapest agglomerációs övezetében helyezkedik el (hét db).

Az elkövetkező időszak egyik legfontosabb területfejlesztési kérdése, hogy a magasan képzett munkaerő migrációs mintázatában történhet-e strukturális változás - amely nélkülözhetetlen eleme lenne a közép- és nagyvárosok versenyképességének erősítésének. A humán tőke vonzása és megtartása tekintetében közép- és nagyvárosaink „,halmozottan hátrányos helyzetűnek" tekinthetők, hiszen nem csupán Budapesttel kell felvenniük a versenyt, hanem a külföldi metropoliszokkal is.

További fontos kérdés, hogy a gazdasági-társadalmi szempontból túlsúlyos Budapest mely településekre fejti ki inkább túlcsorduló, s melyekre inkább elszívó hatását. Illetve milyen tényezők határozzák meg, hogy Budapest közelségéből profitálnak-e, vagy versenyhátrányt szenvednek. A településmintát áttekintve az látható, hogy a dimenziók többségében alulmaradó települések Budapesthez való közelségük ellenére sem tudnak kiemelkedni, amíg a már hagyományosan is előnyösebb adottságú települések önerősító módon sikeresen aknázzák ki térbeli helyzetükból adódó előnyöket.

\footnotetext{
VARGA VIRÁG

Budapesti Corvinus Egyetem Gazdaságföldrajz, Geoökonómia és Fenntartható Fejlődés Tanszék, Budapest virag.varga@uni-corvinus.hu
} 
Teveli-Horváth Dorottya

Budapesti Corvinus Egyetem Gazdaságföldrajz, Geoökonómia és Fenntartható Fejlődés Tanszék, Budapest

dorottya.teveli-horvath@uni-corvinus.hu

HoRZSA GERGELY

Társadalomtudományi Kutatóközpont, Budapest

horzsa.gergely@tk.hu

\section{IRODALOM}

Aininger, K.-Firgo, M. 2015: Regional Competitiveness Under New Perspectives (October 29, 2015). WWWforEurope Policy Paper No. 26. https://doi.org/10.2139/ssrn.2685585

Ambrus Z.-Kissné M. M.-Kólyáné Sz. Á.-MalakuCZiné, P. M. 2008: Nagyvárosok összehasonlító vizsgálata. - Területi Statisztika 11.(48.) 2.pp. 136-163.

BAKOS L.-né et al. 1985: A szomszédos megyék középfokú vonzáskörzetébe tartozó települések Hajdú-Bihar megyei helyzete és népességmegtartó-képessége. - Területi statisztika, 35.2. pp. 295-315.

BARCA, F. 2009: An agenda for a reformed cohesion policy. A placed-based approach to meeting European Union challenges and expectations. http://www.europarl.europa.eu/meetdocs/2009_2014/documents/regi/ dv/barca_report_/barca_report_en.pdf (Letöltés: 2020.01.10.)

BELUSZKY P. 2014: Budapest-zászlóshajó vagy vízfej? - Szent István Egyetemi Kiadó, Gödöllő 172 p.

BELUSZKY P.-GyôRI R. 1999: A magyarországi városhálózat és az EU-csatlakozás. - Tér és Társadalom, 13. 1-2.pp. 1-30. https://doi.org/10.17649/TET.13.1-2.510

BELUSZKY P.-GYŐRI R. 2004: Fel is út, le is út... Városaink településhierarchiában elfoglalt pozícióinak változása a 20. században. - Tér és Társadalom, 18. 1. pp. 1-41. https://doi.org/10.17649/TET.18.1.929

BóDi F.-BôHM A. 2000: Sikeres helyi társadalmak Magyarországon. - Agroinform Kiadóház, Budapest 180 p.

Bourdieu, P. 1989: Social Space and Symbolic Power. - Sociological Theory 7.1. pp. 14-25.

Bourdieu, P. 2004: Gazdasági tőke, kulturális tôke, társadalmi tőke. - In: ANGELusz R. (szerk.): A társadalmi rétegződés komponensei. - Új Mandátum Könyvkiadó, Budapest, pp. 122-137.

Burger, M. J.-VAn DER KNAAP, B.-WALl, R.S. 2014: Polycentricity and the Multiplexity of Urban Networks, European Planning Studies 22.4. pp. 816-840. https://doi.org/10.1080/09654313.2013.771619

CAMAGNI, R. 2005: The rationale for territorial cohesion: issues and possible policy strategies. - In: BosCAINO, P. (ed.): Present and future of the European spatial development perspective. Alinea, Firenze, pp. 121-138.

CAmagni, R. 2008: Towards a concept of territorial capital. - In: CAPello, R.-CAmagni, R.-Chizzolini, B.-Fratesi, U. (eds.): Modelling regional scenarios for the enlarged Europe. Springer, Berlin, pp. 33-48.

CAmagni, R. 2009: Territorial capital and regional development. - In: CAPELlO, R. - NiJKAMP, P. (eds.): Handbook of regional growth and development theories. Edward Elgar, Northampton, pp. 118-132. https://doi.org/10.4337/9781848445987.00014

CAPELlo, R. 2015: Regional economics. 2nd ed. Routledge, London, New York. https://doi.org/10.4324/9781315720074

Csomós Gy. 2009: A regionális központok szerepének változása Magyarország városhálózatában a szabad királyi városoktól a NUTS régióközpontokig, Tér és Társadalom 23.2. pp. 97-111. https://doi.org/10.17649/TET.23.2.1237

Csomós Gy. 2016: Magyarország gazdasági központjainak pozícióváltozása 1992 és 2011 között. - Területi Statisztika 53.6. pp. 529-550.

EC. 1999: Sixth Periodic Report on the Social and Economic Situation and Development of Regions in the European Union. European Commission, Luxembourg

EGEDY T. 2012: A gazdasági válság hatása a nagyvárosok versenyképességére Magyarországon. - Földrajzi Közlemények 136.4. pp. 420-438.

ERDŐSI F. 2002: Gondolatok a közlekedés szerepéről a régiók/városok versenyképességének alakulásában. - Tér és Társadalom 16. 1. pp. 135-159. https://doi.org/10.17649/TET.16.1.840

FabBro, S.-Mesolella, A. 2010: Multilevel spatial visions and territorial cohesion: Italian regional planning between the TEN-T corridors, ESDP polycentrism and Governmental ,Strategic Platforms'. Planning, Practice and Research, 1., pp. 25-48. https://doi.org/10.1080/02697451003625364

FISCHER, M.-NiJKAMP, P. 2014: Handbook of regional science. - Springer, Heidelberg. https://doi.org/10.1007/978-3-642-23430-9 
FLORIDA, R. 2002: The Rise of the Creative Class: And how It's Transforming Work, Leisure, Community and Everyday Life. - Basic Books, New York 481 p.

Glossop, C. 2008: Housing and economic development - Moving forward together, Housing Corporation, Centre for Cities $42 \mathrm{p}$.

GlaESER, E. L.-BERRY, C. L. 2005: The divergence of human capital levels across cities. - National Bureau of Economic Research - $52 \mathrm{p}$.

Granovetter, M. 1977: The Strength of Weak Ties. - American Journal of Sociology, 78. 6., pp. 1360-1380.

GYURIS F. 2014: Az egyenlőtlen földrajzi fejlődés koncepciója. - Földrajzi Közlemények, 138. 4. pp. 293 -305.

Herbert, D.-Smith, D. 1989: Social Problems and the City. - Oxford University Press, Oxford 271 p.

HoRvÁth, Gy. 2013: The regional structure and decentralisation of science in Central and Eastern Europe. - In: PÁlné Kovács, I.-Scott, J.-GÁl, Z. (szerk.): Territorial cohesion. For the 70th anniversary of the Transdanubian Research Institute. Institute for Regional Studies Centre for Economic and Regional Studies, Hungarian Academy of Sciences, Pécs, pp. 196-207.

JANCSÓ T.-SZALKAI G. 2017: A magyarországi felsőoktatási vonzáskörzetek jellemzői, az intézmények elérhetősége és a középiskolák szerepe a jelentkezésekben. - Földrajzi Közlemények, 141. 4 pp. 370-385.

JónA GY. 2013: A területi tőke fogalmi megközelítései. - Tér és Társadalom 27.1. pp. 30-51. https://doi.org/10.17649/TET.27.1.2449

KolTAi Z. 2005: A magyarországi városok versenyképességének lakossági megítélése. - Tér és Társadalom 19. 3-4. pp. 23-41. https://doi.org/10.17649/TET.19.3-4.1017

Koltai Z. 2015: Településtípusok lakóhelyi vonzerőinek értékelése. - Földrajzi Közlemények, 139.3.pp. 213-225.

KolTAi Z. 2019: Magyarországi gazdasági központok és mobilitási hajlandóság a telephelyi tényezők tükrében. - Földrajzi Közlemények, 143. 4. pp. 324-338.

KovÁcs Z.-SzaBó T. 2013: A policentrikus városfejlődés térfolyamatai Közép-Európában. - Településföldrajzi Tanulmányok, 2.1. pp. 6-19.

KŐSZEGFALVI GY. 2014: A magyarországi községhálózat a 2011-es népszámlálás adatainak tükrében. - Területi Statisztika, 54.3. pp. 271-288.

LeFF, S.-Petersen, B. 2015: Beyond the Scorecard: Understanding Global City Rankings. - The Chicago Council on Global Affairs. http://www.thechicagocouncil.org/sites/default/files/BeyondtheScorecardReport.pdf

LENGYeL B. 2012: Tudásalapú regionális fejlődés. - L’Harmattan, Budapest 168 p.

LENGYEL I. 2000: A regionális versenyképességről. - Közgazdasági Szemle, 12, pp. 962-987.

LENGYel I.-VAS Zs. 2015: Várostérségek eltérő fejlődési pályái Magyarországon. - In: RicZ A.-TAKÁcs Z. (szerk.): A régió TÍZpróbája. Regionális Tudományi Társaság, Szabadka pp. 35-48.

LőRINCZ K.-KôVÁRI E. M.-BANÁsz Zs. (2020): Miért jó Szentesen élni? - Egy hazai kisváros lakosságának életminősége és helyi kötődése. - Földrajzi Közlemények, 144. 1.pp. 112-131. https://doi.org/10.32643/fk.144.1.8

LuKÁCS G. 2008: Sikeres vidék. - Szaktudás Kiadó Ház, Budapest 224 p.

Lukovics M.-ZuTi B. 2014: Sikeres egyetemek a régiók versenyképességének javításáért: „,negyedik generációs” egyetemek. MPRA Paper No. 78276, posted 24 Apr 2017 14:26 UTC Elérhető: https://mpra.ub.uni-muenchen.de/78276/ (Letöltve: 2020.01.11.)

Lux G. 2013: Az ipari parkok a területi versenyképességben: telephelyek vagy fejlesztési csomópontok? - In: KISS É. (szerk.): A hazai ipari parkok különböző dimenzióban. Dialóg Campus Kiadó, Budapest, Pécs, pp. $294-309$.

MAKRA L.-SÜMEGHY Z. 2010: Magyarországi városok és megyék osztályozása infrastrukturális és környezeti indikátorok alapján. - Földrajzi Közlemények, 134.2. pp. 203-215.

Matolcsi L. 1982: Az urbanizáció hatása a közigazgatásra, egy középfokú szerepkörű település tükrében. Szakdolgozat, Budapest.

Meyer-Stamer, J. 2008: Systemic competitiveness and local economic development. Mesopartner, Duisburg

Molnár E.-DÉzsi Gy.-LengYel I.-KozMA G. 2018: Vidéki nagyvárosaink gazdaságának összehasonlító elemzése, Területi Statisztika, 2018, 58.6. pp. 610-637. https://doi.org/10.15196/TS580604

Nemes-NAGy J.-Lő́cSEI H. 2015: Hosszú távú megyei ipari növekedési pályák (1964-2013). - Területi Statisztika, 2015, 55.2. pp. 100-121.

Nemes-NAGY J. 2007: Kvantitatív társadalmi térelemzési eszközök a mai regionális tudományban. - Tér és Társadalom 21.1. pp. 1-19.

OECD. 2001: OECD Territorial Outlook, Territorial Economy http://www.vwl.tuwien.ac.at/hanappi/AgeSo/SecReps/Territorial_Outlook_F.pdf (Letöltés: 2020.01.10)

PÁlnÉ Kovács I. 2014: Miért hagytuk, hogy így legyen? A területi decentralizációs reformok természetrajza Magyarországon. - Politikatudományi Szemle 22.4. pp. 7-34.

PÉLI L.-KÁPOSZTA J.-NÉMEDINÉ K. K. 2017: A megyei jogú városok átfogó gazdaságfejlesztése a modern városok programon keresztül - középpontban az infrastruktúra-fejlesztés, Studia Mundi-Economica 4.4. https://doi.org/10.18531/Studia.Mundi.2017.04.04.49-58

Putnam, R. 1995: Bowling Alone: America's Declining Social Capital, - In: Lin J.-Mele CH. (szerk.): The urban sociology reader, $2^{\text {nd }}$ Edition, Routledge, Abington, pp. 
RECHNitZER J.-CSIZMADIA Z.-GRosz A. 2004: A magyar városhálózat tudásalapú megújító képessége az ezredfordulón, Tér és Társadalom, 18. 2. pp. 117-156. https://doi.org/10.17649/TET.18.2.949

Rechnitzer J.-Grosz A. (szerk.) 2005: Régiók és nagyvárosok innovációs potenciálja Magyarországon. MTA-RKK, Pécs-Győr

ReChnitZer J.-PÁthy Á.-BERKEs J. 2014: A magyar városhálózat stabilitása és változása, Tér és Társadalom, 28. 2. pp. 105-127. https://doi.org/10.17649/TET.28.2.2623

SALAmin G. 2004: A gazdasági térszerkezet alakulásának legújabb folyamatai. Falu Város Régió, 11.9. pp. 14-24.

Salamin G.-Kígyóssy G.-Borbély M.-Tafferner B.-Szabó B.-Tipold F.-Péti M. 2014: A fejlesztéspolitika és területfejlesztés új koncepciójáról: Az Országos Fejlesztési és Területfejlesztési Koncepció és a 2005-ös országos területfejlesztési koncepció érvényesítésének tapasztalatai. Falu Város Régió 20.1.pp. 7-24.

SALAmin G.-LENGYel I.-GuTPINTÉR J. 2016: Regionális különbségek a gazdasági növekedésben Magyarországon.

SAlamin G.-RAdVÁnszKi A.-NAgY A. 2008: A magyar településhálózat helyzete, Falu Város Régió 2008 (3). pp. 6-26.

SAlAmin G.-PÉTi M.-CZIRA T. 2005: Paradigmaváltás küszöbén: Az új Országos területfejlesztési koncepció és a területi tervezés. Területi Statisztika 8.5. pp. 423-439.

SALÁnCZI I.-FEKETE T. 1985: A településfejlesztés és a falusi népesség változásának összefüggései Győr-Sopron megyében. Területi statisztika, 35.3. pp. 331-342.

Stiglitz, J. E.-Sen, A.-Fitoussi, J.P. 2009: Report by the commission on the measurement of economic performance and social progress. Commission on the Measurement of Economic Performance and Social Progress, Paris

SzÁSz A. 1984: Aprófalvak - nagy felelősség. - In: SüKÖSD F. (szerk.): Az aprófalvak közélete és ifjúsága. Kisz Baranya megyei Bizottsága, Pécs. pp. 153-165.

Tóтн B. I. 2011: A magyar középvárosok teljesítménye a területi tőke tükrében, Területi Statisztika 14.5. pp. $530-543$.

То́тн B. I. 2013: The relations between territorial capital and regional and urban development - the case of Hungarian medium size cities, Széchenyi István Egyetem, doktori disszertáció

Tóтн G.-NAGY Z. 2013: Same or Different Development Paths? A Comparative Study of the Large Cities and Regions in Hungary, Regional Statistics, 4.1. pp. 100-119. https://doi.org/10.15196/RS04107

Tóтн K. 1982: Tények és érvek a Békés megyei községek népességmegtartó képességéről. Területi statisztika, 32.1-2. pp. 40-59.

VARGA A. 2009: Térszerkezet és gazdasági növekedés. Akadémiai Kiadó, Budapest

Waterhout, B.-Meijers, E.-Zonneveld, W. 2005: Polycentric Development Policies in Europe: Overview and Debate, Built Environment 31.2.pp. 163-173. https://doi.org/10.2148/benv.31.2.163.66250 